\title{
Muž davu
}

\section{Man of the Crowd}

\author{
Walter Benjamin
}

\begin{abstract}
This original translation of Walter Benjamin's text belongs among his fragmentary, unfinished sketches, exploring the changing urban society of the nineteenth century, most of which was finally published under the title Passageways. Benjamin draws on the citations from the literary production of the late nineteenth century and uses it to derive the theoretical image of the city life in the upcoming industrial age. Much more then in the detailed imagery of the city itself, he is interested in the changes to which its inhabitants are subordinated, experiencing the pressures of their environment. Benjamin notices the changing perception structures of the modern man and finds its symbolic expression in the „man of the crowd“.
\end{abstract}

KEY WORDS urban citizen, city space, flaneur, literary image of a city, London, Paris

Poeova známá povídka Muž davu je něco jako rentgenový snímek detektivního př́iběhu. Svrchní látka, již představuje zločin, zde odpadla. Zbyla armatura: pronásledovatel, dav, neznámý, který si volí cestu Londýnem tak, aby zůstával uprostřed lidské masy. Tento neznámý je flanér par excellence. Tak jej také chápal Baudelaire, když flanéra v eseji o Guysovi nazval l'homme des foules. Poeova charakteristika této postavy je však prosta tichého přitakání, které do ní vložil Baudelaire. Pro Poea je flanér především ten, kdo špatně snáší vlastní společnost; proto hledá dav; a odtud je zřejmě jen krůček k pochopení důvodu, proč se v davu schovává. Rozdíl mezi asociálem a flanérem Poe záměrně stírá. Muž je tím podezřelejší, čím hưře je pro druhé nalezitelný. Vypravěč uzavírá, zříkaje se delšího pozorování: „,Tento starý muž je ztělesněním, je duchem zločinu, ‘ řekl jsem si. ,Nedokáže být sám; je to muž davu. ““

Čtenářův zájem si zde nežádá jen povídka sama; přinejmenším stejně pozoruhodné je Poeovo líčení davu - a to jak z dokumentárních, tak z uměleckých důvodů. Je mimořádné v obou ohledech. Co překvapí nejdřív, je, jak vášnivě vypravěč sleduje divadlo davu. To sleduje, ve známé povídce E. T. A. Hoffmanna, také bratranec z okna na rohu. Jak ulpívavě se však davem probírá zrak toho, kdo je vetknut do své domácnosti. A jak pronikavý je pohled muže, který zírá skrze okna kavárny. V rozdílu pozorovacích stanovišt' se odráží rozdíl mezi Berlínem a Londýnem. Němcovy hranice jsou těsné. A přece byl Hoffmann z rodu Poeů a Baudelairů. V biografických poznámkách k původnímu vydání jeho posledních spisů mimo jiné stojí: „Povahou nebyl Hoffmann nikdy obzvláštní př́tel. Člověk, rozhovor s ním, pozorování, pouhé vidění člověka bylo mu nade vše. Šel-li v lé-

Sociální studia. Fakulta sociálních studií Masarykovy univerzity, 2/2006. S. 35-38. ISSN 1214-813X.

Překlad je převzat z: Benjamin, Walter: Das Paris des Second Empire bei Baudelaire, Aufbau-Verlag, Berlin und Weimar 1971, s. 77-84. 
tě na procházku, což za pěkného počasí bývalo denně zvečera, sotva se našel vinný šenk, cukrářství, kam by nezašel na kus řeči, aby viděl, zda jsou tam lidé a jací.“ Později si i člověk jako Dickens znovu a znovu stěžoval - v dopisech ze svých cest - na nedostatek pouličního ruchu, který prý k psaní nutně potřeboval: „Nemohu ani vypovědět, jak velmi mi chybějí ulice,“ psal roku 1846 z Lausanne během práce na románu Dombey a syn. „Je to, jako by mému mozku dávaly něco, co tento, má-li pracovat, nemůže postrádat. Týden, čtrnáct dní dokážu výtečně psát na odlehlém místě. Jeden den v Londýně pak stačí, abych se vzpružil ... Ale abych psal den co den bez této magické lampy, to mě stojí nesmírně mnoho úsilí a práce ... Moje postavy jako by se zastavovaly, když kolem sebe nemají dav.“ Z mnoha věcí, které Baudelaire vytýkal nenáviděnému Bruselu, ho obzvláštním vztekem naplňovala jedna: „Žádné výkladní skříně. Flanerie, již národy s fantazií milují, v Bruselu není možná. K vidění tu není nic a ulice jsou nepoužitelné.“ Baudelaire miloval samotu; ale chtěl ji mít v davu.

Poeovi se v průběhu povídky setmí a on pak prodlévá s městem ve svitu plynových lamp. Zjev ulice coby interiéru, v němž se shromažd'uje flanérova fantasmagorie, lze od plynového světla sotva oddělit. Plynové osvětlení bylo nejprve zavedeno v pasážích. Za Baudelairova dětství došlo k prvnímu pokusu uplatnit je také pod širým nebem; na Place de Vendôme postavili kandelábry. Za Napoleona III. počet pařížských plynových lamp rychle rostl. Bezpečnost ve městě se zvýšila; dav se v ulicích i v noci cítil jako doma; to vymazalo z obrazu velkoměsta hvězdné nebe spolehlivěji než vysoké domy. „Zatáhnu závěs za sluncem. Odešlo do postele, jak se sluší; já ted' neuvidím jiného světla než plynových plamenů."1 Měsíc a hvězdy už nestojí za zmínku. V dobách rozkvětu druhého císařství nezavíraly obchody na hlavních třídách večer před desátou hodinou. Byla to velká doba nočního života. „Člověk,“ psal tehdy Delvau v Heueres parisiennes v kapitole věnované druhé hodině po půlnoci, ,si může čas od času odpočinout; zastávky a přestávky jsou mu dovoleny; ale nemá právo spát.“ Dickens u Ženevského jezera melancholicky vzpomíná na Janov, kde měl dvě míle ulic, v jejichž světle se za nocí mohl toulat. Později, když s vymíráním pasáží vycházela z módy i flanerie a také plynové světlo už neplatilo za vznešené, zdálo se poslednímu flanérovi, který smutně bloumal prázdnou pasáží Colbert, že plápolání kandelábrů odráží už jen strach plamenů, že koncem měsíce nebudou zaplaceny. Stevenson tehdy psal svou stížnost na mizení plynových lamp. Poukazuje v ní především na rytmus, v němž lampáři v ulicích rozsvěceli jednu lucernu za druhou. Nejdřív se lišil od rovnoměrnosti stmívání, ted' ovšem od šoku, jímž se celá města naráz ocitají ve svitu světla elektrického. „Takové světlo by mělo dopadat jen na vrahy nebo zločince proti státu či osvětlovat chodby v blázincích - pro hrůzu, aby stupňovalo hrůzu.“" Ledacos mluví pro to, že plynové světlo bylo teprve později vnímáno tak idylicky jako u Stevensona, který mu píše nekrolog. To nám potvrzuje především Poeův text. Účinek tohoto světla lze sotva líčit přízračněji: „Paprsky plynových luceren byly zprvu, kdy se ještě mísily s večerním soumrakem, slabé; nyní získaly nadvládu a vrhaly kolem plápola-

Stejný obraz v Crépuscule du soir: nebe se zatahuje pomalu jako velká alkovna (s. 90, in: Baudelaire: Oeuvres complètes, Paris 1961; platí i pro další Benjaminovy citace Baudelaira, pozn. překl.) 
vé a oslepivé světlo. Všechno vyhlíželo černě, přitom však třpytivě jako ebenové dřevo, s nímž byl srovnáván styl Tertulliánův.“ „Uvnitř domu, “ čteme u Poea na jiném místě, ,je plyn naprosto nepřípustný. Jeho plápolavé tvrdé světlo uráží oko.“2

Pochmurně a těkavě jako světlo, v němž se pohybuje, působí i sám londýnský dav. To neplatí jen o li̊ze, která s nocí „vylézala z děr“. „Skupinu lepších úředníkư“ Poe líči takto: „Všichni byli mírně plešatí a jejich pravá ucha, za která si už léta zastrkují pero, jim většinou nepěkně odstávala. Všiml jsem si, že smekají a opět si klobouky nasazují oběma rukama a že nosí hodinky na krátkých zlatých řetízcích bohatého a starobylého vzoru." Poeovy popisy nemírí k bezprostřednímu zrakovému dojmu. Druhová stejnost, jižz maloměšták podléhá svým bytím v davu, je přehnaná; jeho šat nemá daleko $\mathrm{k}$ uniformě. Ještě pozoruhodnější je popis davu podle způsobu, jakým se pohybuje. „Lidé, kteří tu procházeli, měli většinou spokojené obchodnické vzezrèní a zřejmě přemýšleli jen o tom, jak se protlačit dál; když do nich vrazil protijdoucí občan, neprojevili ani trochu nedůtklivosti, jen si narovnali kabát a hned zas šli svou cestou. Jiní - a těch bylo také hodně - měli neklidné pohyby, zardělé obličeje, vykládali rukama a hovořili pro sebe, jako by jim právě ta stmelená masa kolem dávala pocit samoty. Když se těmto lidem někdo postavil do cesty, přestávali sice mumlat, zato však tím prudčeji gestikulovali a vyčkávali s nepřitomným, přehnaným úsměvem, co lidé, kteří jim překážejí, udělají. Když do nich někdo vrazil, uctivě se mu klaněli a zřejmě je to nadobro vyvedlo z míry. “3 Člověk by se právem domníval, že je řeč o přiopilých, zubožených individuích, náležejících k lumpenproletariátu. Avšak předmětem popisu jsou ,šlechtici, obchodníci, advokáti, kupci, spekulanti.“ Zde je ve hře něco jiného než psychologie tř́í. ${ }^{4}$

Existuje litografie od Senefeldera, která představuje hráčský klub. Ani jeden z těch, kdo jsou na ní zpodobeni, se nevěnuje hře běžným způsobem. Každý podléhá nějakému afektu; jeden nevázané radosti, druhý nedůvěře ke spoluhráči, další tupé beznaději, další hádavosti; jeden se chystá skoncovat se životem. Toto dílo připomíná extravagancí Poea. Poeova

2 Edgar Allan Poe: <éd. Gallimard: Ch. B. Hist. Extraordinaires, traduits d'Edgar A. Poe, Paris 1928, p. 53, Philosophie del'ameublement $>$. Překlad této citace převzat od Věry Saudkové (Benjamin, W.: Dílo a jeho zdroj, Praha 1979, s. 110, pozn. 4), ostatní dle Josefa Schwarze (Poe, E. A.: Zrádné srdce. Výbor z díla, Praha 1959, s. 285-298); pozn. překl.

3 K tomuto místu existuje paralela v Un jour de pluie. Tato báseň, ač signována jiným autorem, je Baudelairova (srv. Charles Baudelaire: Vers retrouvés, éd. Jules Mouquet, Paris 1929). Analogičnost posledního verše $\mathrm{s}$ Poeovou zmínkou o Tertulliánovi je tím pozoruhodnější, že báseň byla napsána nejpozději r. 1843 - v době, kdy Baudelaire o Poeovi neměl tušení.

Chacun, nous coudoyant, sur le trottoir glissant,

Egod'ste et brutal, passe et nous éclabousse,

Ou, pour courir plus vite, en s'éloignant nous pousse.

Partout fange, déluge, obscurité du ciel:

Noir tableau que'eüt ręve le noir Ezéchiel

(s. 214)

4 Obraz Ameriky, jak je vlastní Marxovi, je zřejmě z téže látky jako Poeovy popisy. Marx zdůrazňuje „horečně mladistvý pohyb materiální produkce“ ve Státech a právě ten činí zodpovědným za to, že „,nebyl čas ani prríležitost ... vymést staré zásvětí.“ U Poea má v sobě démonično už samotná fyziognomie obchodníků. Baudelaire líčí, jak se setměním ve vzduchu procitají „líně jak kupecká chátra zlí běsi.“ Je možné, že toto místo v básni Crépuscule du soir (s. 90) ovlivnil Poeův text. 
výčitka je ovšem silnější, čemuž odpovídají i jeho prostředky. Mistrovský tah jeho popisu spočívá v tom, že beznadějnou izolovanost lidí ve svých soukromých zájmech nevyjadřuje rozdílností gest jako Senefelder, nýbrž bezproblémovou stejností, at' už je to oblékání anebo chování. Servilita, s níž se ti, kteří sklízejí rány, ještě omlouvají, napovídá, odkud se berou prostředky, které zde Poe volí. Jsou z repertoáru klaunů. Poe jich užívá podobně, jako později excentrikové. Na úkonech excentrika je zjevná souvztažnost s ekonomií. Trhavými pohyby imituje právě tak mašinerii, která buší do hmoty, jako konjunkturu, která buší do zboží. Podobnou mimésis „horečných pohybů materiální produkce“ včetně s ní spjatých forem obchodu vytvářejí prvky davu líčené Poem. U Poea se předjímá to, čeho později svými kostitřasy a podobnými atrakcemi docílil lunapark, který z občánka dělá excentrika. Lidé se v jeho popisech chovají tak, jako by se už dokázali vyjádřit jen reflektoricky. Rej působí tím odlidštěněji, že řeč je jen a jen o lidech. Stává-li se dav neprůchodným, není to proto, že by mu bránily vozy - o dopravě není ani zmínky -, nýbrž proto, že jej ucpávají další zástupy. Flanerii se v mase tohoto druhu nemohlo obzvlášt' dařit.

Baudelairova Paříž ještě taková nebyla. Ještě existovaly př́ivozy, které se plavily přes Seinu tam, kde později postavili mosty. V roce Baudelairova úmrtí mohl ještě přijít podnikatel s nápadem dát pro pohodlí zámožných občanů do oběhu pět set nosítek. Ještě byly v oblibě pasáže, v nichž byl flanér ušetřen pohledu na povoz, nepřipouštějící konkurenta - chodce. Pěší, který se vmáčkne do davu, existoval; ale existoval také flanér, který potřebuje prostor a nechce se vzdávat soukromí. Bezcílně si chodí jako osobnost; protestuje tak proti dělbě práce, jež z lidí dělá specialisty. A právě tak protestuje proti jejich přičinlivosti. Kolem roku 1840 patřilo na čas k bontonu brát si na procházky do pasáží želvy. Flanér jim rád dovolil určovat tempo. Kdyby bylo po jeho, musel by se takovému tempu naučit i pokrok. Avšak poslední slovo neměl on, nýbrž Taylor, který prosadil heslo „Pryč s poflakováním“. Někdo se pak ještě včas snažil načrtnout kontury toho, co mělo následovat. „Flanér,“ píše r. 1857 Rattier v utopii Paris n'existe plus, ,jehož bývalo vidět na chodnících a před výlohami, tento nicotný, bezvýznamný, věčně okounějící typ, který lovil emoce za šesták a neměl ponětí o ničem než o dlažbě, fiakrech a plynových lampách..., ten je dnes zemědělcem, vinařem, majitelem cukrovarů a továren, zpracovatelem lnu a železa.“

Muž davu se na svých potulkách dostává k bazaru, i v pozdní hodinu značně zalidněnému. Pohybuje se tu jako ve známém prostředí. Existovala za Poea už víceposchod'ová nákupní centra? At' je tomu jakkoli, Poe zde svého štvance nechá strávit ,přribližně půl druhé hodiny“. „Vstupoval do jednoho krámu po druhém, nikde se však nezajímal o zboží, nepromluvil slovo a jen s šíleným, prázdným pohledem všechno obzíral.“ Je-li pasáž klasickou formou interiéru, jako který se flanérovi představuje ulice, pak jeho úpadkovou formou je obchodní dům. Obchodní dům je flanérovou poslední štací. Jestliže se mu ulice v počátcích měnila v interiér, tak nyní se interiér proměnil v ulici a on bloudí labyrintem zboží jako předtím labyrintem města. Velkolepým tahem Poeova vyprávění je, že do nejranějšího popisu flanéra vpisuje postavu jeho konce. ${ }^{5}$

\section{Přeložila Daniela Blahutková}

Př́ibuzné úvahy rovněž in Benjamin, W.: Dílo a jeho zdroj, Praha 1979, kapitola O některých motivech u Baudelaira, zvl. od s. 92 (pozn. překl.). 